\title{
EU-CIRCLE methodological approach for assessing the resilience of the interconnected critical infrastructures of the virtual city scenario to climate change
}

This paper introduces a methodological approach for identifying the resilience of interconnected EU critical infrastruc-

\author{
Theodoros Katopodis ${ }^{1}$, \\ Athanasios Sfetsos ${ }^{1}$, \\ Vasiliki Varela ${ }^{1}$, \\ Stelios Karozis ${ }^{1}$, \\ Georgios Karavokyros, \\ Georgios Eftychidis ${ }^{2}$, \\ Ilias Gkotsis², Georgios Leventakis², \\ Ralf Hedel $^{3}$, Ifigenia Koutiva ${ }^{4}$, \\ Christos Makropoulos ${ }^{4}$ \\ ${ }^{1}$ INRASTES, NCSR Demokritos, \\ Patr. Gregoriou E' \& 27 Neapoleos St., \\ 15341 Agia Paraskevi, Greece \\ Email ts@ipta.demokritos.gr \\ ${ }^{2}$ Center for Security Studies, \\ P. Kanellopoulou St. 4, \\ 10177 Athens, Greece \\ ${ }^{3}$ Fraunhofer Institute for Transportation \\ and Infrastructure Systems, \\ Dresden, Germany \\ ${ }^{4}$ School of Civil Engineering, \\ NTUA, Athens, Greece
} tures to climate change. The proposed approach tries to establish a consequence-based modelling framework for assessing climate-dependent causal relationships between CI operation and response to climate impacts with an aim to minimise disruptions to service flows under diverse conditions. The proposed study provides a description of the virtual city's forest fire and smoke reference scenario with their optional damages to the electricity transmission and distribution network.

Keywords: risk assessment, interconnection analysis, holistic impact analysis, European critical infrastructures, climate change 


\section{INTRODUCTION}

The main scope of the proposed approach is to propose a scientifically verified framework to estimate the resilience of critical infrastructures (CI) to climatic hazards. According to the recently published IPCC AR5 report, climate change-related risks to infrastructures are increasing with widespread negative impacts on local and national economies and ecosystems [11]. As CI are critical components to the normal functioning of modern EU societies, their resilience encompasses the operational component in addition to its structural integrity and its capacity to maximize business output under climate stressors $[3,4]$. On the other hand, the increasingly dependent, interdependent and interconnected nature of EU critical infrastructures exposes previously unseen risks, new vulnerabilities and opportunities for disruption across the CI networks [10]. Our proposed methodological framework is based on a synthesis of various policies for providing validated scientific support for national and European policies [5-7]. Research projects with impacts related to natural hazards and climate change in the same manner include ARMONIA (511208) MEDIGRID (FP62003-Global-2-004044) project, Na.RAs, EPSON, ENSURE (FP7/212045), FUME (FP7/243888), WEATHER project (233886), EWENT (233919), CLIM-RUN project (FP7-ENVIRONMENT 265192). Other ones are focused on the impacts on the urban environment and CI, such as RESIN (653522), PLACCARD (653255), CIPRNET (312450), INFRARISK (603960), INTACT (606799), RAIN (608166), STREST (603389). On a national scale, several approaches and guidance documents exist such as the German from BMI (Protecting Critical Infrastructures - Risk and Crisis Management), the Dutch DHM (De Haagse Methodiek - The Hague Method) and NRB (Nasjonalt risikobilde - Norwegian national risk chart), the CPNI/UK Civil Contigencies Act, and the Norwegian Risk Vulnerability Analysis. A set of quantitative probabilistic risk analyses of a single CI, such as the Risk and Vulnerability Analysis, the Preliminary Hazard Analysis (PHA), and the Probabilistic Safety Analysis and Quantitative Risk Analysis have been proposed but require specialized knowledge to be applied [15], while Haimes et al. [8] offer a methodological framework that recognizes, programmes, evaluates and manages risks to complex, large-scale systems. In recent years, some of the most prominent approaches are the following: (IRRIIS (128735), DIESIS (212830)), (I2SIm simulator) [2], while Rinaldi et al. [13] first tried to model the interdependencies of $\mathrm{CI}$ as highly interconnected and mutually dependent systems. Thereupon, an initial 'virtual city' dataset based on the real-world environment of Rethymno has been generated, containing interconnected critical infrastructure assets and networks. In this approach, the forest fire climate hazard simulations and the potential impacts on the CI (electricity, road, water) are presented.

\section{DEVELOPMENT OF THE METHODOLOGICAL FRAMEWORK}

The main idea of the proposed approach is that any asset within a CI can cause several implications to the interdependent assets or networks. The applied modelling and simulation tools will estimate how the CI state (or its assets) are depended on its former state and/or the states of its interconnected assets. The state of an interconnected asset is hence a consequence of the climatic pressure influencing the originating asset, the resilience of the asset/network (risk mitigation, means of instant response, safety equipment) and the type of interconnection among the assets. A Consequence-based Risk Management approach will be followed as it is depicted in Fig. 1, which incorporates uncertainty in all phases of climate risk modelling and quantifies the risk to societal systems and subsystems.

\section{Climate data and climate hazards analysis}

The initial condition of the analysis is the climate scenario. Different climate information can be used as input to the risk assessment including: (i) output from Global Climate Models (usually at low spatial resolution) reaching up to the year 2100 and obtained from different RCP scenarios; (ii) dynamically downscaled Regional Climate Models with higher resolution and very low temporal analysis; (iii) statistically downscaled climate information; (iv) historical information, derived either from in-situ observations, satellite monitoring or re-analysis of datasets. The output of the climate models includes the likelihood of the event and 


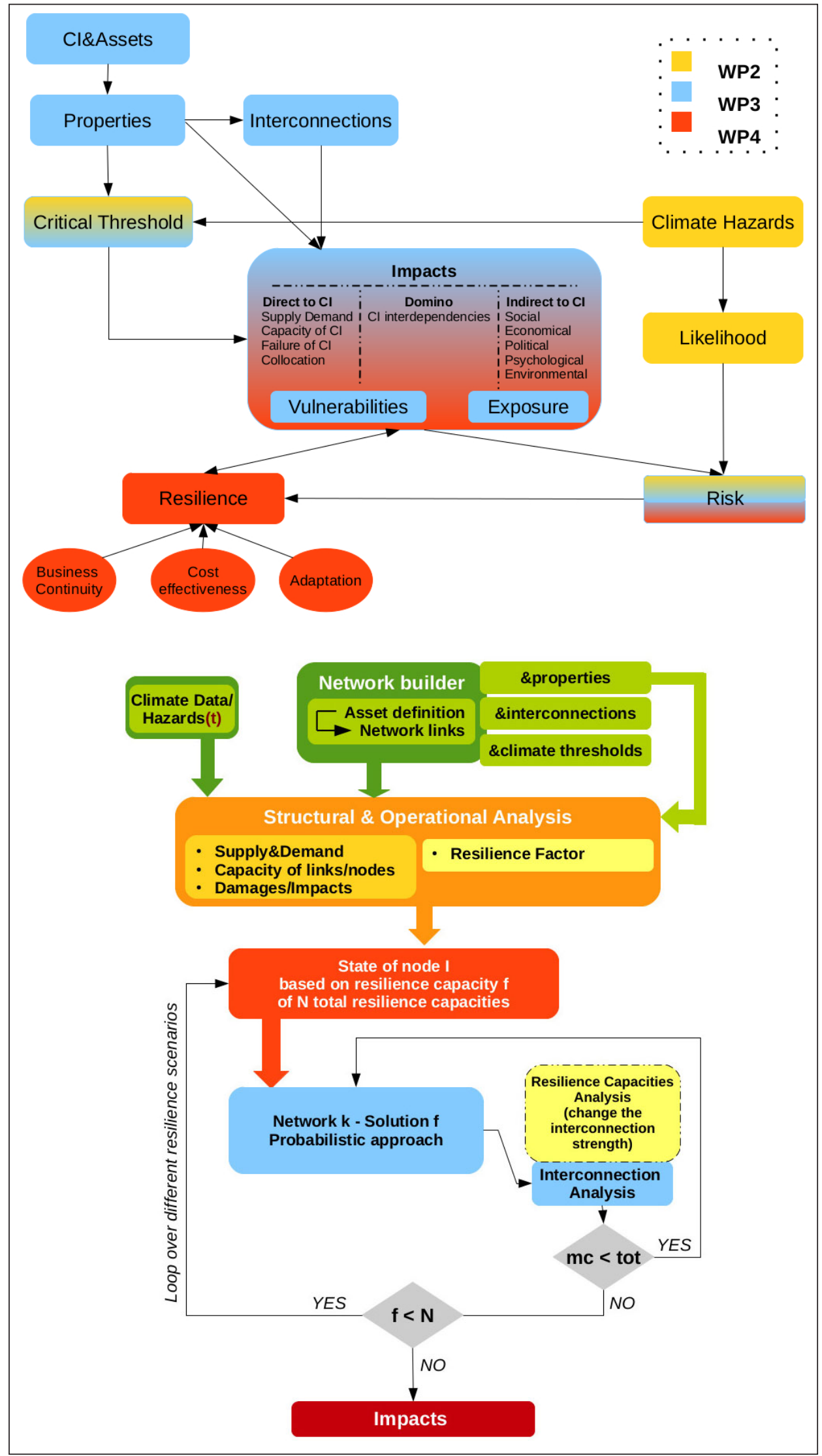

Fig. 1. EU-CIRCLE framework high level description and methodology approach 
the related climate information (single value, spatial/temporal extend). Additionally, it can provide input for secondary climate hazards models (forest fire spreading, flood modelling, drought, etc.).

\section{Registry of CI assets}

For each type of infrastructure, the following elements such as direct assets, auxiliary assets, flow of people, goods and services, input/output, accessibility and capacity will be determined. Additionally the identification of interconnections, interdependencies and appointment of CI assets will be identified, depending on the type: physical, geographical, logical [13]. Each complex asset has been attributed properties and values needed for the follow-on analysis [1].

\section{Induced damages functions}

Under the proposed modelling framework, climate hazard conditions impact components of CI systems causing damages and mal-functions in their capacity and/or also possible disruptions in supply and demand and capacity on the networks nodes which performs changes on the network attributes. These characteristics are generally described by impact models, fragility curves and damage-functionality relationships based on approach in [9].

\section{Network analysis}

The proposed approach introduces a network interdependency analysis between different types of networks of CI as a core modelling component. In that event we suggest a more generic approach, describing the network as a graph (nodes and links), with a characteristic value of flow for each link. This approach permits to solve the network using graph theory solutions, independent of the network type. Moreover, an interdependency network analysis can be performed with additional information about interconnections (types and properties) between the separate networks. As a consequence, the proposed approach is based on a probabilistic network model analyzed for each scenario. For solving the BAU (Business As Usual) scenario and every proposed resilience-based modification, the network analysis solves each network flow independently and then captures its interconnections, depending on the type of each network.

\section{Assessment of consequences}

Climate change already has far-reaching impacts on infrastructures and can put their operation, capacity potential and reliability at increased risk [12]. Infrastructure system performance can be measured with either simple metrics that only depend on the topological characteristics of a network system, or more elaborate metrics that depend on flow patterns and supply/demand in addition to the topological characteristics. As a result the performance of an infrastructure can be easily estimated through the Connectivity Loss (CL) and Service Flow Reduction (SFR) methods.

\section{Quantifying risk}

The Risk Assessment Framework (RAF) has been conceptualized in accordance with National Rental Affordability Scheme (NRAs) and guidance found in Directive 114/2008/EU, using an ordinal scale of 5 categories. The Risk Assessment Matrix applied, thus, is a classic tool to perform a semi-quantitative risk assessment, extensively applied in countless different frameworks. Some basic principles that were implemented within the present RAF are presented accurately at the EU CIRCLE deliverable 3.4A Holistic CI Climate Hazard Risk Assessment Framework.

\section{FIRE DANGER AND FOREST FIRE SIMULATION SCENARIO WITH SMOKE}

This approach provides for the build of the fire danger and forest fire simulation reference scenario used for the evaluation of the EU-CIRCLE outputs. Each scenario encompasses a build phase and a test phase. The geoview of the cumulative dataset resulting with all the infrastructure and auxiliary elements of the virtual city is presented in Fig. 2:

- Digitizing and mapping of the various network layers of virtual case study;

- Build of the required infrastructure, assets, models, etc. within the virtual spatial database.

\section{Network asset description}

This section provides an overview of the main assets that constitute the virtual dataset. The assets have been provided in two different asset types: 


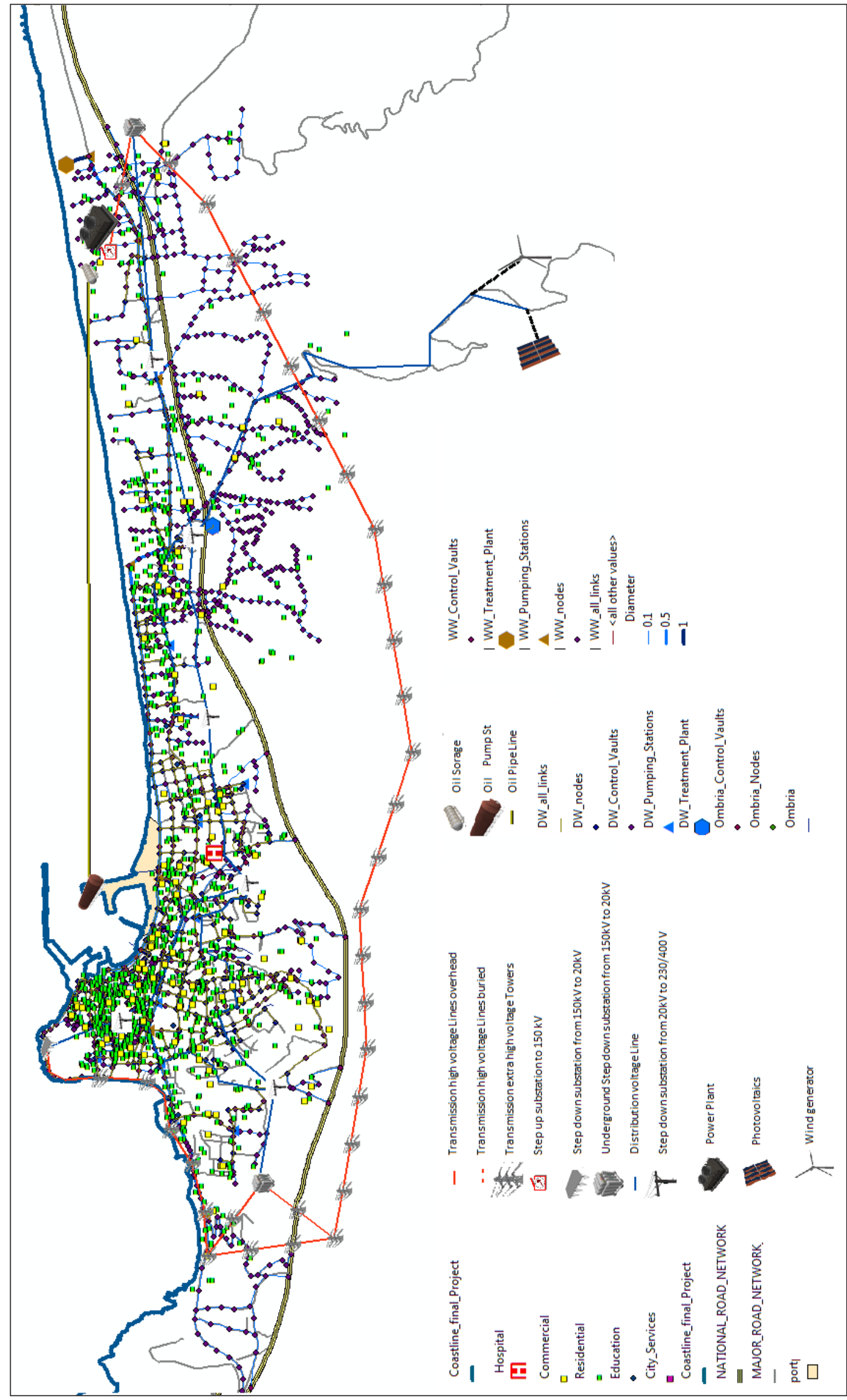

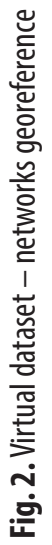


- Nodes: describing assets located in a single area, but geographically represented within this dataset as a point.

- Links: describing assets covering a line segment geographically represented within this dataset as a linear element.

The network describes the assets forming a network and includes additional operational/ services properties of the network such as Generation, Flow, Capacity, etc.

\section{FWI virtual city "Rethymno"}

The forest fire danger study is based on the daily calculation of two indexes (Fire Weather Index and Drought Code) of the Canadian FWI system for the area of interest, using seasonal and climatic data forecasts [16]. Further processing and analysis of the daily values of the indexes such as Extreme Value Theory, mapping of weekly averages, amount of days with high FWI values, etc. provide valuable information about the spatial and temporal distribution of forest fire danger in the area. The selection of extreme fire weather scenarios for the forest fire simulation is based on this analysis. The weekly maps presenting FWI classes for four weeks of summer 2016 are presented in Fig. 3.

\section{Forest fire simulation scenario with smoke}

The virtual city's forest fire and smoke scenario is based on the meteorological data of 18 August 2050 of the scenario RCP8.5 for the area of Rethymno, Crete, Greece. The weather conditions for that day were strong west winds, prolonged high temperatures and low relative humidity values. These conditions are related to low fuel moisture content and intense fire regime. The fire burned a forested area covered by typical Mediterranean vegetation (i.e. open aleppo pine forest, dense shrubs, grasslands). The simulation was performed for six hours with a 30 minutes step, and the smoke simulation was calculated for the event. The CI assets affected by the fire event and the released smoke are defined using Spatial Overlay analyses functions. The fire propagation steps and the smoke simulation are shown in the following images together with the affected CI assets (Figs. 4, 5).

\section{Damages}

Fire smoke propagation can make straight harm to transmission poles and other electricity infrastructure. However, damage risk derives from a) smoke and PM that can ionize the air, creating an electrical path away from conductors and b) heat of fire in case they were not burned.

Transmission lines and towers are fundamental elements of the electricity transmission network. Since transmission lines often run through pasturelands and woodlands, it makes them especially vulnerable to wildfires. Figure 6 shows the effects of the fire event and the released smoke in the electricity network transmission and distribution lines in the study area. As it is considered, more than ten transmission poles and several distribution poles are expected

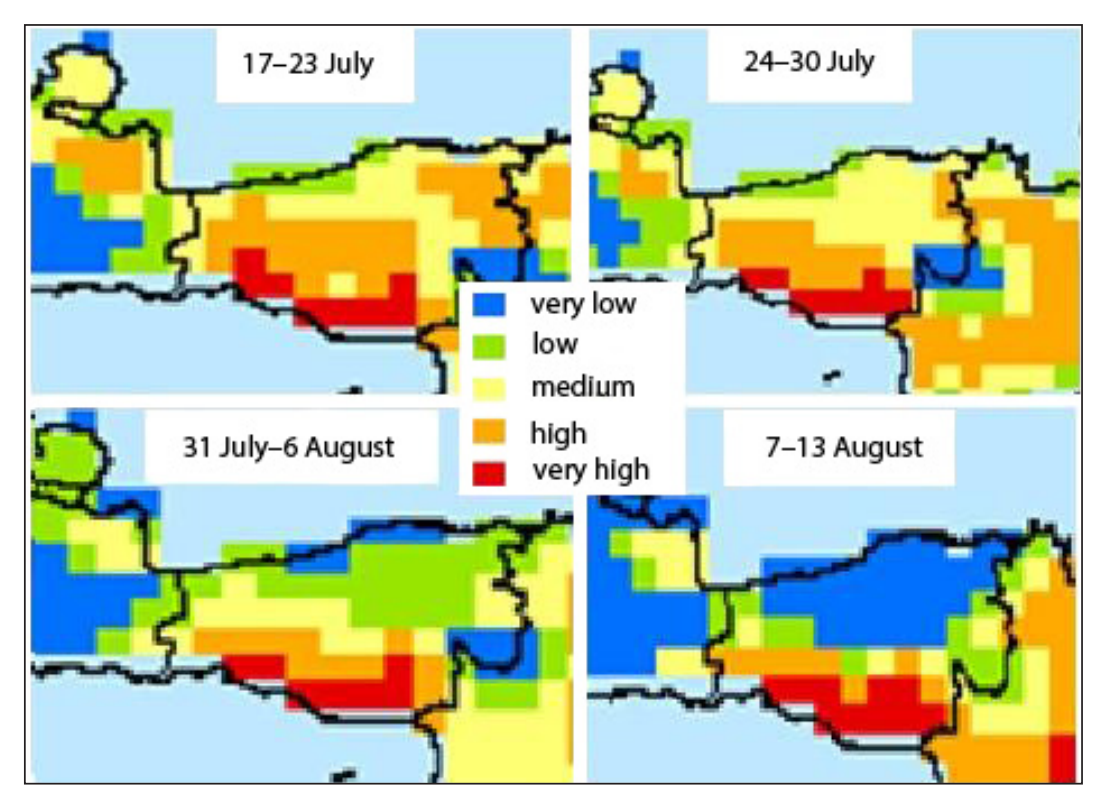

Fig. 3. Weekly maps of FWI classes for summer 2016, using seasonal weather forecasts 


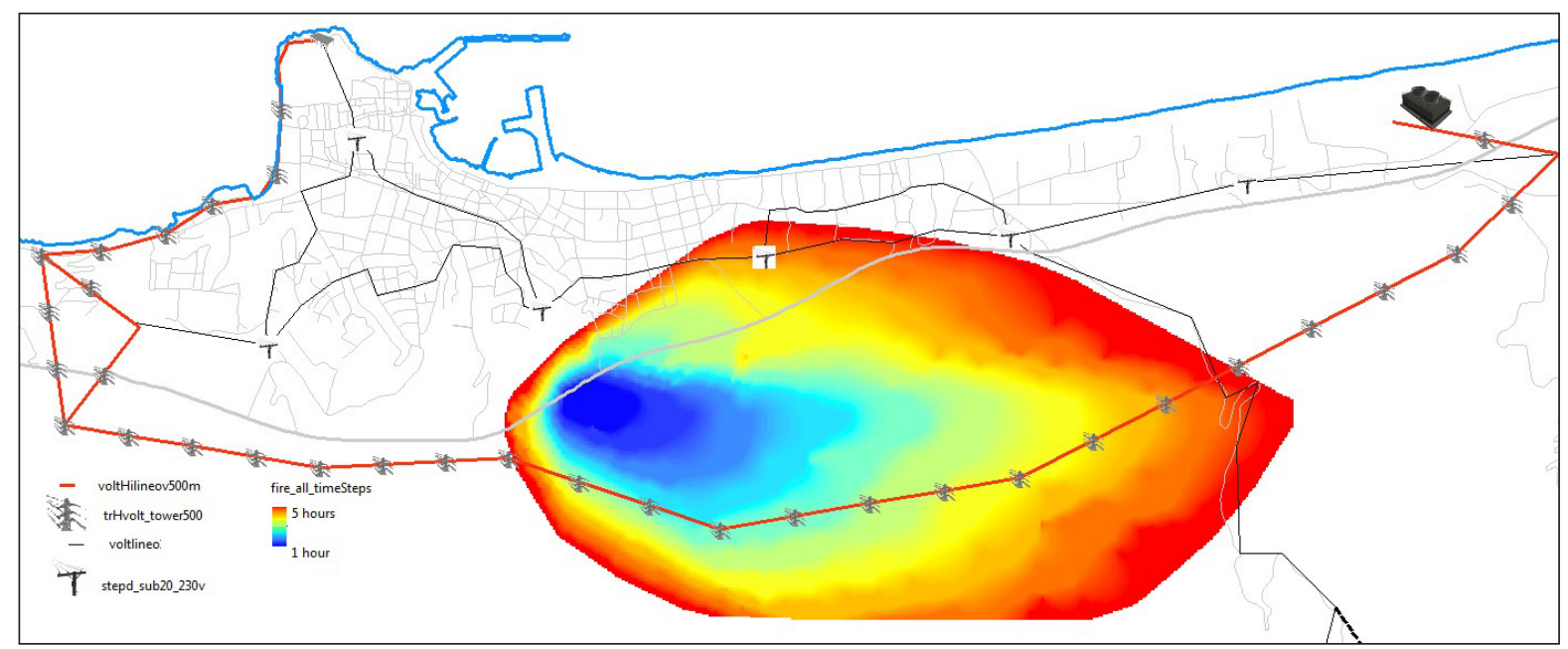

Fig. 4. Fire propagation for 6 hours in 30 minutes time-steps

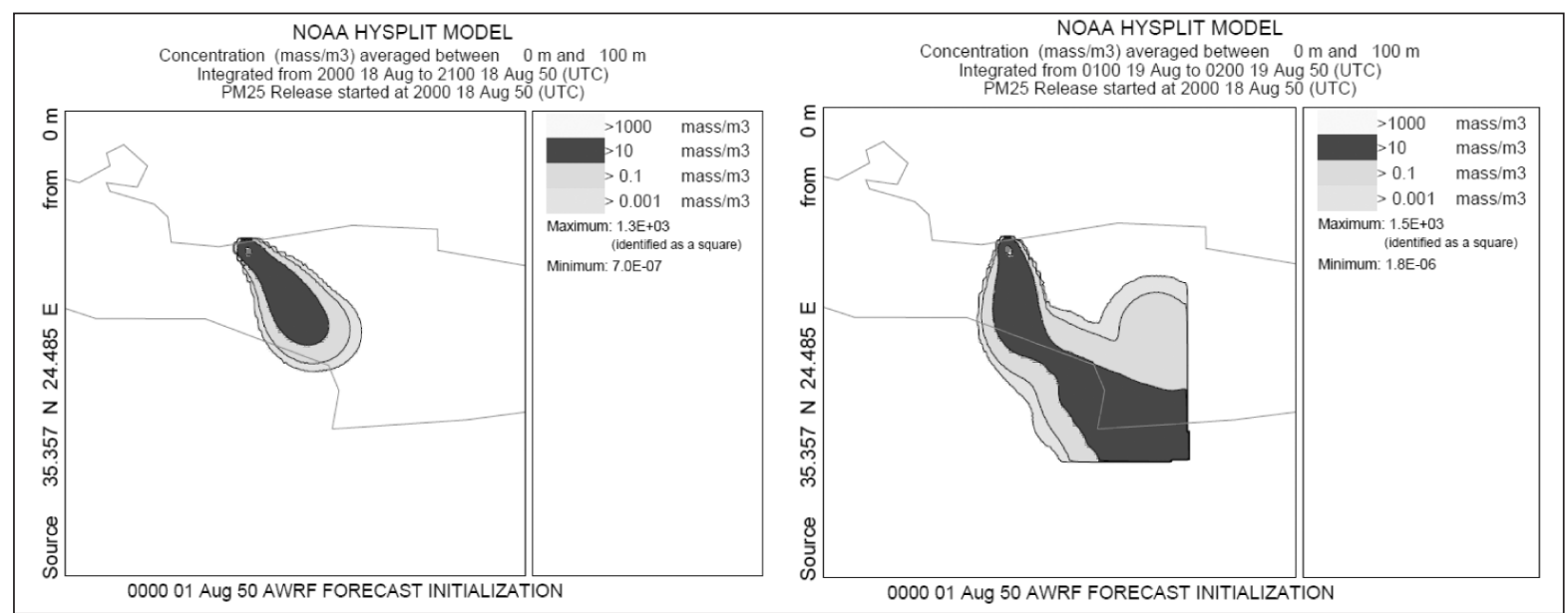

Fig. 5. Fire smoke propagation $(t=0 \& t=6 \mathrm{~h})$

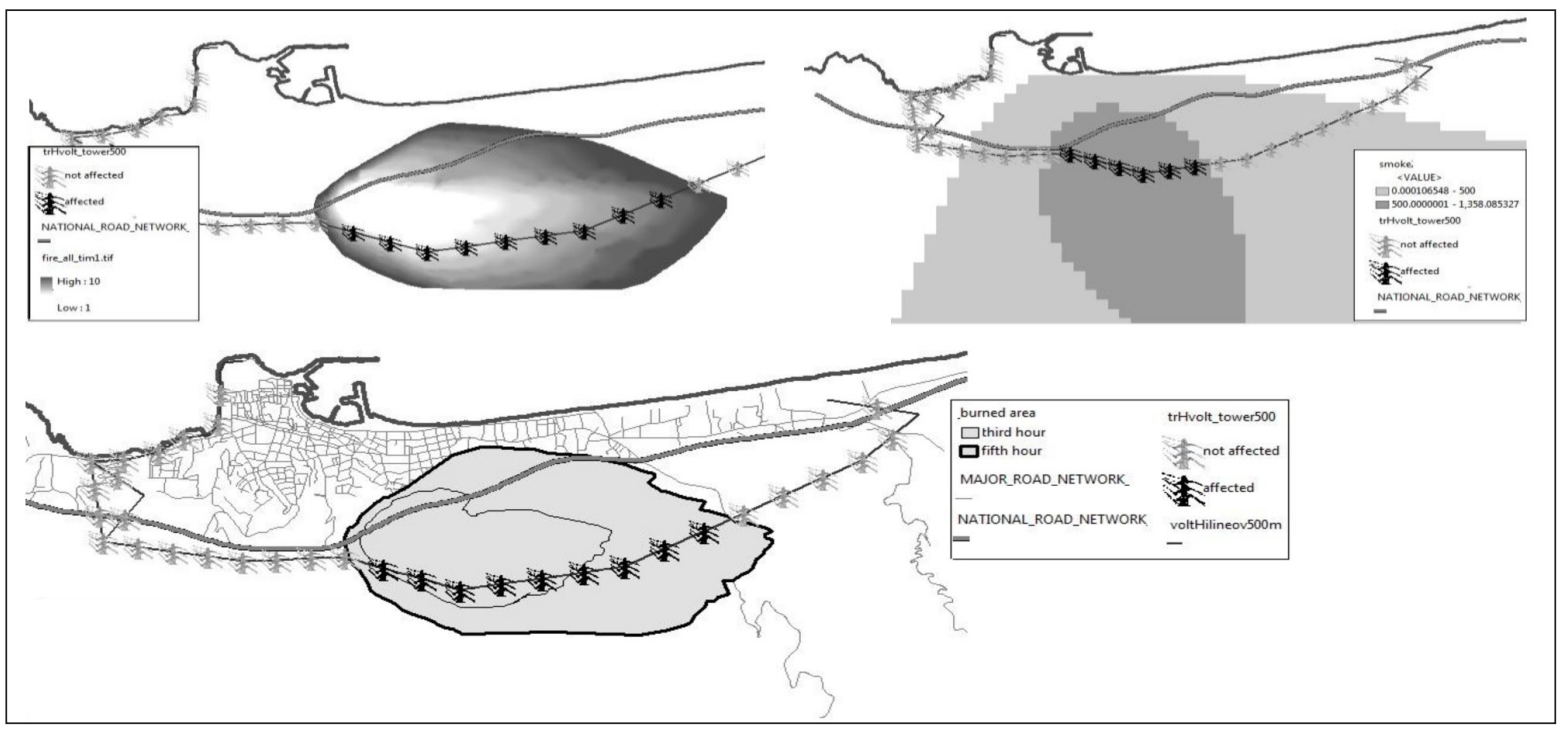

Fig. 6. Electricity network assets affected by the fire event and the released smoke 
to be damaged, resulting in a long-term loss of the electric power to majority of the study area, with potential damages to the other interconnected infrastructures.

\section{CONCLUSIONS}

This work introduced a methodological approach for assessing the resilience of European CI to emerging challenges such as climate change. The document presented so far the virtual data generated within the framework of the EU-CIRCLE project with forest fire scenario and smoke scenario related to extensive disruption to interconnected CI operation. The increasing risk of forest fires is an element which was taken into account, as recent events (2017) in Portugal demonstrated. From simulations conducted since now, results conclude to the evidence that electricity grid failures are substantially related to smoke and fires, as fire and smoke propagation can close down the lines and produce power outages with optional diverse impacts on other interconnected assets or networks.

\section{ACKNOWLEDGEMENTS}

This project has received partial funding from the European Union's Horizon 2020 research and innovation programme under grant agreement No 653824 - EU-CIRCLE

Received 16 January /2018 Accepted 14 March 2018

\section{References}

1. Bollinger L. A., Bogmans C. W. J., Chappin E. J. L. et al. Climate adaptation of interconnected infrastructures: a framework for supporting governance. Regional Environmental Change. 2013. DOI: 10.1007/s10113-013-0428-4.

2. Casalicchio E., Galli E., Tucci S. Agent-based modelling of interdependent critical infrastructures. International Journal of System of Systems Engineering. 2010.

3. CEN (2002) Eurocode-Basis of Structural Design. Available at: https://www.unirc.it/documentazione/materiale_didattico/599_2010_260_7481.pdf.
4. Dimova S., Fuchs M., Pinto A. et al. State of implementation of the Eurocodes in the European UnionSupport to the implementation, harmonization and further development of the Eurocodes. 2015. DOI: 10.2788/854939. Available at: http://eurocodes. jrc.ec.europa.eu/ (accessed 17 February 2016).

5. EC (2008) On the review of the European programme for critical infrastructure protection (EPCIP). EPCIP 114/2008.

6. EC (2013) An EU Strategy on adaptation to climate change. $\operatorname{COM}(2013) 216$ final. Brussels. Available at: http: //ec.europa.eu/transparency/ regdoc/rep/1/2013/EN/1-2013-216-EN-F1-1. Pdf (accessed 30 May 2016).

7. EC (2014) Overview of natural and man-made disaster risks in the EU. SWD (2014) 134. SWD (2014) 134.

8. Haimes Y. Y., Kaplan S., Lambert J. H. Risk filtering, ranking, and management framework using hierarchical holographic modeling. Risk Analysis. 2002; Vol. 22. No. 2. P. 383-397. DOI: 10.1111/0272-4332.00020.

9. Hazus - MH 2.1. Multi-hazard Loss Estimation Methodology Flood Model Technical Manual. Washington, D. C.: Department of Homeland Security Federal Emergency Management Agency Mitigation Division. 2011. Available at: www. fema.gov/plan/prevent/hazus.

10. Hokstad P., Utne I. B., Vatn J. Risk and Interdependencies in Critical Infrastructures. Springer Series in Reliability Engineering. London: Springer London. 2012. Available at: http://link. springer.com/10.1007/978-1-4471-4661-2 (accessed 17 February 2016).

11. IPCC (2018) Climate Change 2014: Impacts, Adaptation, and Vulnerability. Available at: http:// www.ipcc.ch/report/ar5/wg2/.

12. JRC (2018) Loss Database Architecture for Disaster Risk Management. Available at: http://drmkc. jrc.ec.europa.eu/partnership/Science-Policy-Interface/Disaster-Loss-and-Damage-WorkingGroup.

13. Rinaldi S. M., Peerenboom J. P., Kelly T. Identifying, understanding, and analyzing critical infrastructure interdependencies. IEEE Control Systems. 2001. Vol. 26. No. 6. P. 11-25.

14. Steelman J., Song J., Hajjar J. F. Integrated Data Flow and Risk Aggregation for Consequence-Based 
Risk Management of Seismic Regional Loss. University of Illinois. 2007. Available at: https:// www.ideals.illinois.edu/handle/2142/11997 (accessed 31 May 2016).

15. Utne I. B., Hokstad P., Vatn J. A method for risk modeling of interdependencies in critical infrastructures. Reliability Engineering \& System Safety. 2011. Vol. 96. No. 6. P. 671-678. DOI: 10.1016/j.ress.2010.12.006.

16. Van Wagner C. E. Development and structure of the Canadian Forest Fire Weather Index System. Forestry Technical Report 35. Headquarters, Ottawa: Canadian Forestry Service. 1987.
Theodoros Katopodis, Athanasios Sfetsos, Vasiliki Varela, Stelios Karozis,

Georgios Karavokyros, Georgios Eftychidis, Ilias Gkotsis, Georgios Leventakis, Ralf Hedel, Ifigenia Koutiva, Christos Makropoulos

\section{EU-CIRCLE PROJEKTO METODIKA \\ VERTINANT VIRTUALIOJO MIESTO YPATINGOS SVARBOS SUSIJUSIŲ INFRASTRUKTŪRŲ ATSPARUMĄ KLIMATO KAITOS SCENARIJAMS}

\section{Santrauka}

Straipsnyje pristatoma metodika, kaip nustatyti tarpusavyje susietų ES ypatingos svarbos infrastruktūros objektų atsparumą klimato kaitai. Siūloma metodika siekiama sukurti pasekmèmis grịstą modeliavimo sistemą, skirtą vertinti nuo klimato priklausančius priežastinius ryšius tarp ypatingos svarbos infrastruktūros veiksmų ir reagavimo ị klimato poveikị, kad būtų sumažinta ịvairiomis sąlygomis atsirandančių paslaugų srautų sutrikimų. Atliktame tyrime pateikiamas virtualiojo miesto miško gaisrų ir dūmų scenarijaus atvejis, nurodomi jų elektros perdavimo ir paskirstymo tinklui keliami nuostoliai.

Raktažodžiai: rizikos vertinimas, susijusi analizè, holistinè poveikio analizè, europinès ypatingos svarbos infrastruktūros, klimato kaita 